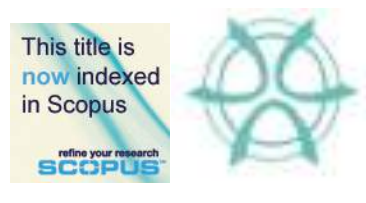

PLANNING MALAYSIA:

Journal of the Malaysian Institute of Planners

SPECIAL ISSUE IV (2016), Page 163 - 180

\title{
THE PROVISION OF VERTICAL SOCIAL POCKETS FOR BETTER SOCIAL INTERACTION IN HIGH-RISE LIVING
}

\author{
Siew Bee, Aw ${ }^{1} \&$ Poh Im, Lim ${ }^{2}$ \\ ${ }^{1,2}$ Faculty of Engineering and Science \\ UNIVERSITI TUNKU ABDUL RAHMAN
}

\begin{abstract}
High-rise living makes it difficult for social communities to form despite the provision of several dedicated social spaces at ground, podium, mid- and roof-levels, partially due to the sheer number of residents per block. The pull of easily-accessed, solitary recreational activities such as surfing the Internet and watching television further exacerbates the problem. Social spaces need to be brought closer to residents to promote social interaction. This paper proposes to improve social interaction by supplementing currently stratified social spaces with vertically-connected social hubs using existing transitional spaces in high-rise living, such as the lift lobby, to create micro-communities comprising the residents of each respective floor in a cost-effective way. Previous research indicated that strong communities look after each other, indicating that the creation of microcommunities will create an effect not unlike the defensible space theory. Therefore, this paper analyses residential high-rise layouts based on chosen case studies in Malaysia, then suggests several possible design outcomes that turn the lift lobby into social spaces at every floor level.
\end{abstract}

Keyword: High-rise living, social interaction, social spaces, vertical connectivity

\section{INTRODUCTION}

High-rise living is fast becoming a dominant part of the urban fabric of Malaysian cities. New launches are overwhelmingly of stratified properties, totaling 20,892 units versus just 4,156 landed units in the second quarter of 2014 (NAPIC, 2014). Sites are planned for efficient land usage, maximising the number of units and essentially creating contained communities within each fenced residential scheme. These communities are easily hundreds of residents strong, and the definition of "community" becomes loosened to merely refer to a group of people who happen to stay in the same place, rather than "a body of persons or nations having a common history or common social, economic, and political interests" (Merriam-Webster, n.d.).

The myriad facilities available in residential blocks, which comprise common, shared spaces on ground, podium and select intermediate levels, do allow for socialisation among residents (Glaeser et al, 2012), but they are not enough. Our trips home are optimised for efficient, impersonal travel, from car to lift to home, with scant chances for social interaction. This is further compounded by high levels of mobility within our society (Kneis, 2009). With no opportunities to come in contact and no reason to 
Siew Bee, Aw \& Poh Im, Lim

The Provision of Vertical Social Pockets for Better Social Interaction in High-Rise Living

purposely seek each other out, meaningful neighbourhood social ties (NSTs) ${ }^{1}$ fail to form. Residents lose the chance to have a support network close at hand and feel no social connection to the place they call home. Social spaces need to be destratified, increased in quantity, more accessible, and closer to smaller groups of residents, yet at the same time be affordable to developers so that they will be willing to do it.

This paper focuses on residential high-rises in Malaysia priced between RM100,000 and RM400,000, which according to NAPIC's Q2 2014 report have the highest sales performances with take-up rates of more than $40 \%$ over the past three quarters. Specifically, the paper will look at the viability of developing vertical social pockets into generators of social interaction to create micro-communities comprising the residents of their respective floors.

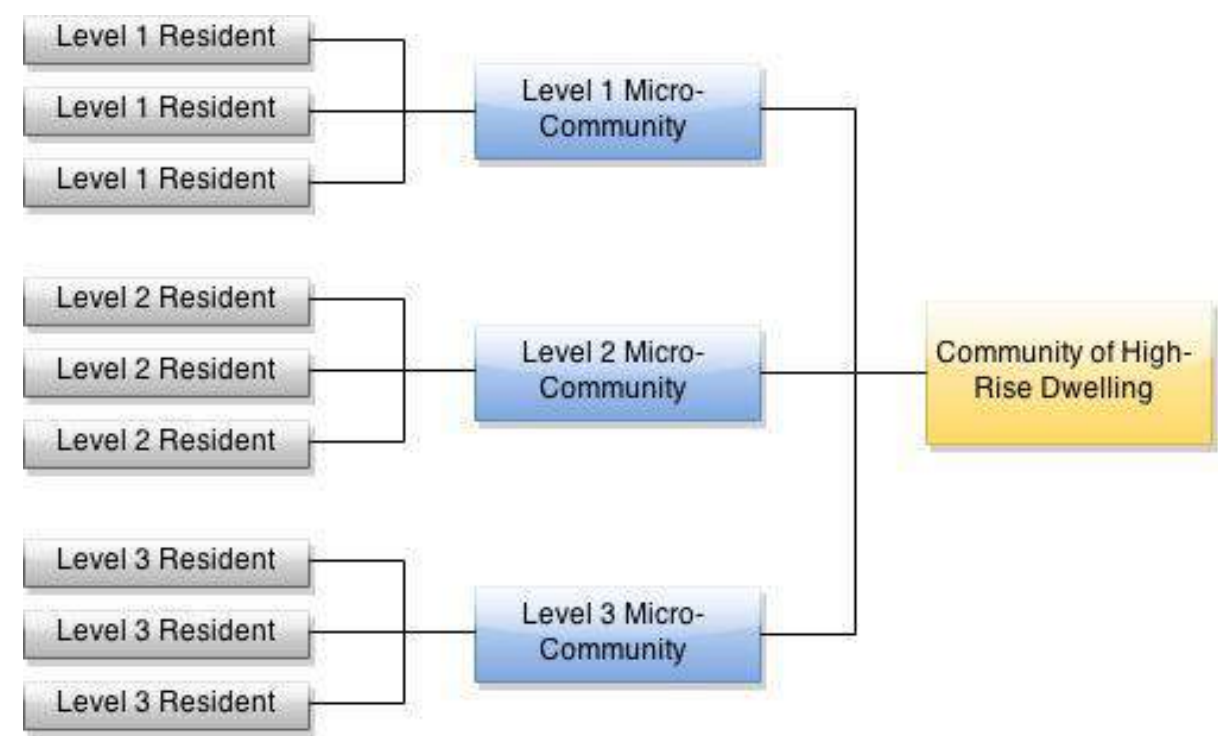

Figure 1: Simplified flow chart of how social relationships among residents can be built up and integrated

\section{High-Rise, High-Density Housing in Malaysia}

A housing environment can be evaluated in terms of its capacity to nurture and sustain social and psychological processes. Interior building design, spatial arrangements and neighbourhood (external or environmental factors) can have potential effects on the quality of spaces. In the context of high-rise residential projects in Malaysia, it is crucial that the hierarchy of different spaces are clearly defined so that it may facilitate the existence of various categories of public, semi-public, semi-private, and private spaces.

Unlike high-density housing estates in Singapore or Hong Kong, many high-rise residential projects in Malaysia have large building footprints, or site coverage. The site coverage of lower and affordable housing categories, which can be as high as $20 \%-60 \%$ of the site, deserves special notice, being much higher than the $12 \%$ site coverage

${ }^{1}$ Connectors of unrelated neighbours to become a neighbourhood (Kuo et al, 1998). 
proposed by Le Corbusier (1932) and the $10 \%$ employed in some of the better public housing schemes in Hong Kong. As a result of this massive site coverage, Malaysian high-rise projects are dominated by concrete towers that suffocate open air-space within the site, which is relegated to building set-backs, roads, and other infrastructure requirements.

The pressure to cut costs and gain profits leads developers to demand maximisation of the sellable area of their projects and minimisation of unprofitable floor area, which refers to areas other than the residential units and accessory parcels, including the semi-public and semi-private transitional spaces in the building. From our observation, the public-private dichotomy in the high-rise, high-density housing environment is obvious. The private space that is the home ends where the long, narrow semi-public corridor begins. The abrupt convergence and inevitable proximity of these two spaces, joined by a short, semi-private foyer, exposes the private lives of the residents to casual surveillance and scrutiny from passers-by, and the awareness of this situation makes them disinclined to entertain strangers. Transitional spaces are designed to encourage passage and discourage meaningless lingering, but in the proper place and with careful design, they can also become social hubs as the potential for chance encounters in such spaces are high.
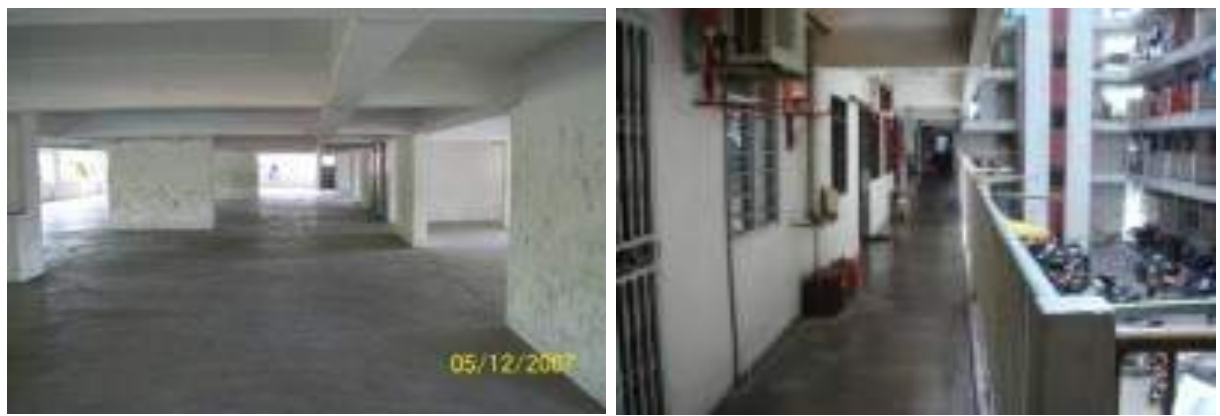

Figure $2 \& 3$ : Existing hostile common spaces and lack of transitional spaces

A lack of social spaces can be stressful for the occupants of a building as it creates a sense of crowdedness. Crowding potentially affects the quality of living of the residents as well as the social cohesion of the community. The condition transcends actual physical space provisions; some of the effects observed include "lack of air, physical discomfort, restriction on movement, high temperatures, [and] odours" (Freedman et al, 1971). Studies of short-term crowding (experimental design that lasted a few hours) have shown that it negatively affects feelings and disrupts performance on complex tasks (Evans, 1979), while long-term crowding can result in lower frustration tolerance, which may translate into social withdrawal or aversion. However, the perception of crowdedness can be sensitively manipulated by design.

\section{Fostering Social Interaction}

According to Maslow (1954), humans are highly social creatures with a strong need to belong, so much so that society has the power to shape who we are (Stets et al, 2013). Social interaction during our formative years dictates, more or less reliably, our 
Siew Bee, Aw \& Poh Im, Lim

The Provision of Vertical Social Pockets for Better Social Interaction in High-Rise Living

behaviours and reactions when we are adults (Hazan \& Shaver, 1987), and extreme cases of social deprivation result in feral children ${ }^{1}$ who cannot function in society. We learn social norms from cues we receive from society, and we either conform to it and remain a member, or go against it and become deviants. So while the first major social institution to influence our lives may be our families, the community we live in by and large exerts its influence the moment we step out of our homes.

In return for our conformity, we become part of a social network ${ }^{2}$ that guides and aids us. In the case of high-rise living, the closest and most constant community can be found among fellow residents. A strong social capital is beneficial for the community. Residents in communities with strong social capital look out for each other, find support groups among themselves, and cooperate for the betterment of the community. It also helps bolster the defensible space theory (Newman, 1972), in which residents become their own security, simply because they feel a sense of ownership of and care for the places around which they interact. According to Newman, "the high-rise elevator building forces more than 500 people to share a common building entry and interior circulation space. The exterior grounds and interior circulation areas are, as a result, anonymous and virtually accessible to anyone...The large number of residents complicates the recognition process among neighbours and discourages opportunity for the development of a commonality of goals and interests among them..." (Newman, 1976).

Evidence has shown that the structure and quality of social interactions have profound effects on psychological, behavioural, and physiological health and well-being (Taylor et al, 1997). Neighbourhoods are intermediate units of social organisation between the home and the city that allow individuals to experience a sense of community and hence improve social health.

Christopher Day (2002) suggested in his book 'Spirit and Place: Healing Our Environment' that the creation of links and nodes can help to generate activities for the community. Dr. Humphry Osmond, former Superintendent of Sasketchewan Hospital, coined terms to describe two basic kinds of spatial arrangements: 'sociofugal space', a space that forces people apart, and 'sociopetal space', a space that pulls people together. Many factors affect the probability and continuity of social interaction amongst members of a community. These include but are not limited to the propinquity effect, similarity, reciprocal liking, and physical attractiveness. These factors can be carried over to highrise living. As many of these factors are uncontrollable, this paper intends instead to encourage several blanket encouragers of social interaction, specifically the propinquity effect.

Festinger (1950) conceptualised the propinquity effect, wherein the frequency of interaction between individuals heightens the chances of forming relationships, which also builds on the mere exposure effect, wherein mere exposure to a stimulus increases liking. Festinger's study is particularly interesting, as it drew a direct correlation between proximity between neighbours, and proximity between units and means of vertical circulation, to friendships among residents. Likewise, Fleming et al (1985) found three variables that improve social interaction:-

i. Opportunities for contact

ii. ii) Proximity between apartments

${ }^{1}$ Feral children are human children who grew up without human contact, care, behaviour or language.

${ }^{2} \mathrm{~A}$ series of relationships that link one person to another. 


\section{iii. iii) Availability of proper places to interact}

The findings of both Festinger and Fleming can be applied to increase the rate of social interaction of an increasingly time-pressed generation without pressuring them to socialise more than they can afford. In the arena of high-rise, high-density urban housing, where large numbers of strangers are forced to live together, provisions for group alteration of the environment is necessary for the development of a communal spirit amongst the residents. As Mitchell (1971) suggested, the organisation of the spaces outside individual dwelling units and buildings may be the key issue to address. Individuals can tolerate high densities in their place of residence, but the same densities may create a street environment that is socially unhealthy for the community. The creation of social pockets within the high-rise itself presents the opportunity to form small group spaces that can foster better social and communal interaction.

\section{Current Housing Policies in Malaysia and Their Effects on Social Interaction Among Residents}

Current housing policies already make the provision of open spaces ('kawasan lapang' in Malay) compulsory for residential projects, varying between $10 \%$ and $15 \%$ of the total land area depending on the state's Local Plan. The guidelines for the provision of common facilities are somewhat looser, as stated in the Draft Planning Guidelines for Common Facilities (2011) under the Town and Country Planning Department of Peninsular Malaysia (Jabatan Perancangan Bandar dan Desa, JPBD), stipulating requirements for only basic facilities such as kindergartens, prayer rooms and multi-purpose halls.

The introduction of a new housing type, the affordable housing unit, in December 2013, created new policies at both federal and state levels. The federal government has announced several policies that are expected to take effect within the next 5-10 years, most notably the PR1MA affordable housing project launched in 2012 under the PR1MA Act 2012, a nationwide endeavour to create 123,000 PR1MA homes by 2015. At state level, there are the Affordable Housing Scheme (Skim Perumahan 100\% Rumah Mampu Milik) in Penang, RUMAWIP in Kuala Lumpur, and the My Home scheme in Kedah, among others, to meet the urgent need for affordable housing in Malaysia.

The guidelines for affordable housing schemes include provisions for facilities, including but not limited to open spaces, playgrounds, religious institutions, and so forth. These common spaces are hubs for social interaction and recreation. The concentration of so many different facilities in one place allows for the formation o like-minded social groups among residents via what Festinger et al termed "passive contact"1.

According to Penang EXCO YB Chow Kon Yeow ${ }^{2}$, the Penang state government is temporarily allowing a special density approval of 87 units per acre for affordable housing schemes in Penang, which is much higher than the typical 15 to 30 units allowed per acre. The reasoning behind this is that the higher number of units, in theory, translates into lower costs per unit that offsets the loss or lower profit margin for affordable housing units. It also means more houses for the masses.

${ }^{1}$ Casual or involuntary meetings, according to Festinger.

${ }^{2}$ As per YB Chow KonYeow's keynote address at the Penang International Conference 2015 on behalf of Chief Minister YAB Lim Guan Eng at Setia SPICE. 
Siew Bee, Aw \& Poh Im, Lim

The Provision of Vertical Social Pockets for Better Social Interaction in High-Rise Living

However, such high density rates should be used in moderation and with caution. Traditionally, communities are smaller in number but more widespread. The inverse happens in high-rise residential living, more so in high-density ones. The high concentration of residents in one place can have an adverse effect on the formation of communities. Studies such as those conducted by McCarthy et al (1978), Baum et al (1979), and Evans et al (2000), have revealed that excessive crowding in high-density living results in social withdrawal ${ }^{1}$, which is detrimental to social interaction. And if residents are unaware of who their neighbours are, high-rise living becomes ripe for crime (Conklin, 1971).

The categorisation of affordable housing projects by price directly limits the type of residents who inhabit them. The different price caps on LCs, LMCs and affordable housing units, and the different minimum total household income necessary to borrow loans to finance the purchase of such units, draws applicants from a specific economic stratum only. For example, a person must earn less than RM2,500 to qualify for an LC unit and RM3,500 for an LMC unit on Penang island, so all residents - assuming they are the owners of the units, as should be - come from that income bracket. This creates a homogeneous community that is both good and bad: on one hand, residents can interact knowing that no one is "better than thou", but on the other hand they may be stuck with certain unpleasant stigmas. For instance, low-cost housing are often associated with lack of hygiene and upkeep, and with a glut of foreigners or otherwise uncouth, perceived dangerous people, when in reality there are also people who are simply making do living there until they can afford a better place to stay.

\section{OBJECTIVES}

The objectives of this research are:

- To increase social interaction among residents in high-rises.

- To locate more areas in high-rises to be turned into social spaces.

- To take a step-by-step approach towards creating cohesive communities in residential high-rises.

\section{APPROACH}

The purpose of this research is to locate and design social spaces conducive for social interaction to create micro-communities comprising the residents of their respective floors. The investigation draws upon literature reviews regarding community and social interaction, as well as a case study of a successful residential social space. It also analyses recent residential high-rise launches in Malaysia priced between RM100,000 and RM400,000, as per the scope of this study, to determine the most common high-rise layouts for residential high-rises within this price range in Malaysia. These data are then used to locate the most appropriate location for social interaction on each floor. Suggestions on how to design the space to make it interaction-friendly is proposed at the end of this study.

${ }^{1} \mathrm{~A}$ retreat from society and interpersonal relationships that may be accompanied by indifference and aloofment. 
ANALYSIS AND DISCUSSION

\section{Case Study: The Traditional House Porch}
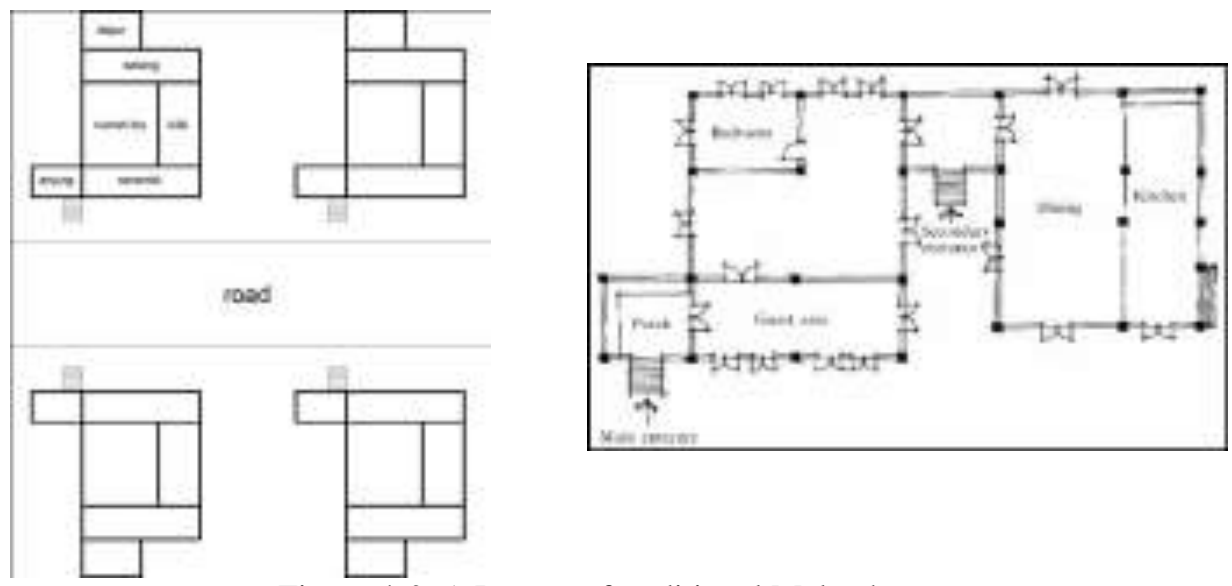

Figure 4 \& 5: Layout of traditional Malay houses

Before malls and cafes became the destinations of choice for those who wish to mingle, the traditional house porch was the closest and most numerous space available for social interaction. In the traditional Malay home, the porch and its entrance, or the 'serambi' and 'anjung' in Malay, is where guests are entertained, and it is normally attached to the front of the house and accessible by a flight of stairs. The 'anjung' has no walls, only railings. Visitors are greeted in the informal, semi-public 'serambi' before being invited into the main living area, or 'rumah ibu' in Malay.

The open nature of the space allows for both active and passive interaction to occur, as everyone is in full view of the streets beyond the house, thus heightening the mere exposure effect even if the interaction consists of just a smile and a greeting. Villagers can drop by if they see their friends on the porch. Residents and their guests will also be able to have their eyes on the streets (Jacobs, 1961), a territoriality that makes the street both safe and humanly welcoming. If the porch is seen as an extension of the street, it becomes a place to pause and linger while staying connected to the main street life.

The ability to visibly recognise individuals as neighbours and to relatively freely visit other villagers' houses leads to high social interaction and meaningful relationships among residents. By being so close to the street front, the porch provides ample chances for chance encounters with both familiar and unfamiliar individuals, thus creating a third place atmosphere that 'anchors' community and fosters interaction (Oldenburg, 1989). These transitional spaces are not unique to local vernacular houses. In other types of conventional housing, a front gate, yard, and vestibule, with windows overlooking the approach, provide warning, preparation time, and vantage points to its dwellers. 
Siew Bee, Aw \& Poh Im, Lim

The Provision of Vertical Social Pockets for Better Social Interaction in High-Rise Living

\section{Common High-Rise Layouts in Malaysia}

This study attempts to identify high-rise layouts commonly used in Malaysia, derived from a random sample from five states with the most new launches of residential units as of Q2 2014 in NAPIC's Property Market Status Report, namely Selangor, Penang, Johor, and the Federal Territories of Kuala Lumpur and Putrajaya. All residential high-rises analysed were launched between 2005 and 2015, and priced between RM100,000 and RM400,000, in line with the scope of this study. In general, these high-rises have aboveground, multi-storey car parks, a single lift lobby, and are topped by common facilities at podium level. A few high-rises also sport common facilities at intermediate and roof-top levels of the building.

\section{The sandwich block}

Upon analysing the new launches in all five states, it is discovered that an overwhelming majority of the new launches utilise the sandwich block, which has a double-loaded central internal corridor flanked by residential units on both sides and punctuated by airwells. In recent years, units within this price range have tended to be below 900 square feet, with three bedrooms and two bathrooms.

The sandwich block is highly efficient in terms of circulation and unit density, resulting in space optimisation which will allow for the construction of more residential blocks within the same parcel of land. Given all the above, it is, therefore, an unsurprising choice of layout for developers who would prefer to maximise the number of units constructed to achieve economies of scale. In this configuration, the lift lobby is usually in the centre of the building layout and the combination of the lifts, staircase and lift lobby takes up one or two column bays. Depending on the span of the bays, this may translate into a narrow lift lobby, although by its location often means that it receives direct sunlight and ventilation from at least one side. The corridors may be dim, especially on the lower floors which have lower sunlight penetration levels.

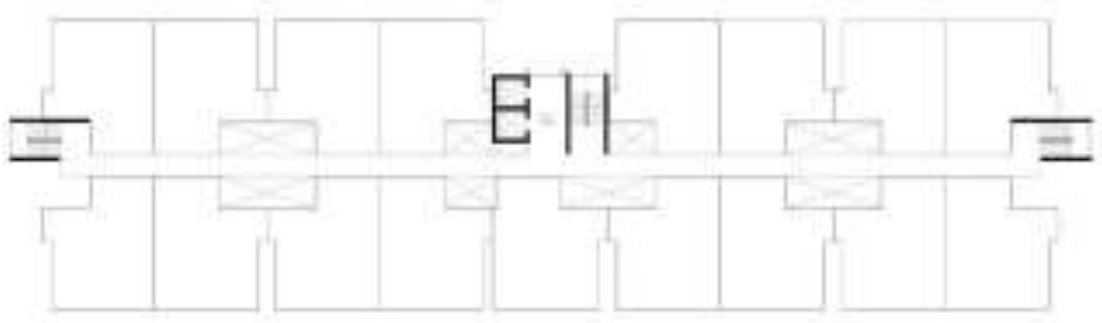

Figure 6: The sandwich block

\section{The point block}

The lift lobby is at the heart of the point block layout. Multiple residential units append to this central core on all sides, linked by a corridor that rings the core for a highlyoptimised circulation route. The residential units in point block high-rises tend to receive ample amounts of natural lighting and ventilation from external facades as they surround a relatively small core. The short corridor and the close placement of units, which eliminates the need for a third staircase normally required to comply with the dead-end 
running distance requirement set by the Fire and Rescue Department of Malaysia (Jabatan Bomba dan Penyelamat Malaysia), potentially translates into cost savings for the developer, who can also benefit from selling their units as having low densities per floor.

The lift lobby in this layout appears bigger due to its seamless connectivity to the corridor around it, and this configuration allows for a wider range of social interaction design interventions. However, as it is situated in the middle of the building layout, it may appear dark and unwelcoming as it receives lighting and ventilation mainly, or solely, from the air-wells around it. The transition from public to private space is especially abrupt.

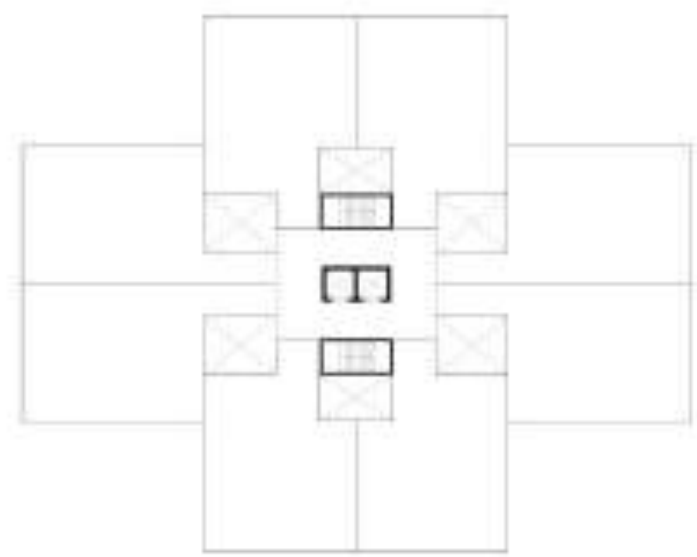

Figure 7: The point block configuration

\section{The single block}

Unlike the sandwich block, which has a double-loaded corridor, the single block utilises a single-loaded corridor in which residential units are laid out on only one side of the corridor. This layout has become increasingly uncommon in recent years as it is, theoretically, only half as efficient as a sandwich block. Regardless, it is still used to suit narrow site constraints that are unable to accommodate wider types of high-rise blocks.

Its transitional spaces receive ample natural lighting and ventilation and as such appear wide and airy. It can also act as a point of convergence if the single block layout is bent to fit the site, with the added benefit of aggrandising the lobby in the otherwise awkward pocket of space created by the maneuvre. As such, transitional spaces in single block layouts stand to be more welcoming and generous than other layouts. 


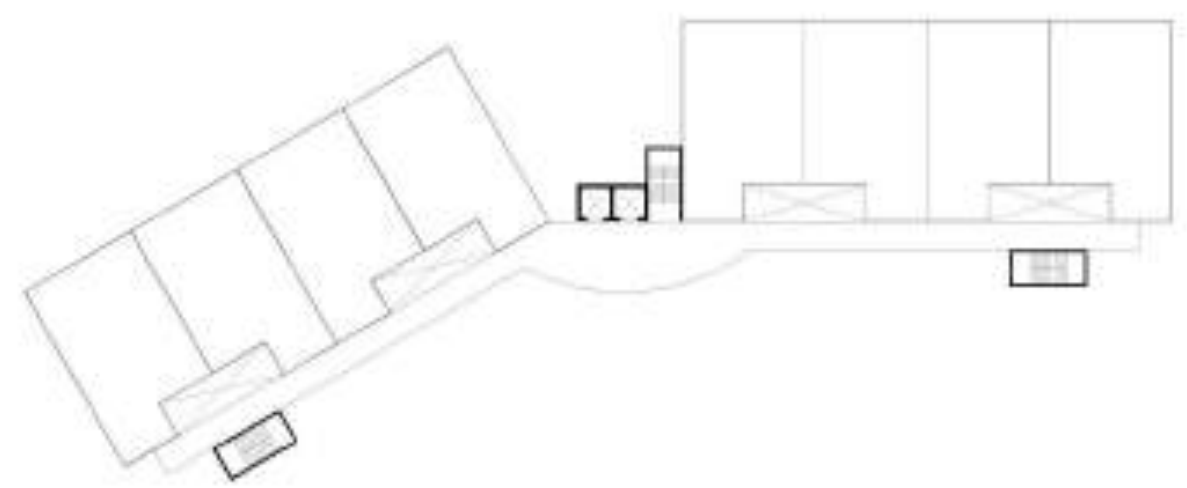

Figure 8: A single block

\section{Hybrids}

Several combinations of the above examples exist, although like the single and point blocks, it is less common than the sandwich block. For example, a combination of singleand double-loaded corridors can be used for irregularly-shaped sites.

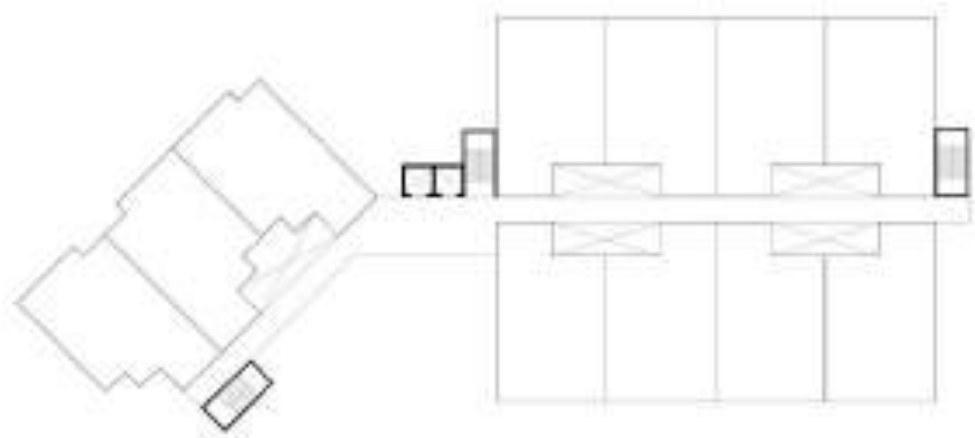

Figure 9: An example of a hybrid block

\section{An Analysis of Existing Common Spaces in Residential High-Rises}

This study proposes to discover a cost-effective way to enhance the sociability of an existing common space in residential high-rises. The semi-public spaces under consideration include green areas, ground-level and podium-level common facilities, transitional spaces such as corridors, staircases, lobbies, as well as service spaces, specifically car parks, as these spaces experience foot traffic and are, therefore, candidates for social triggers in high-rise dwellings. 

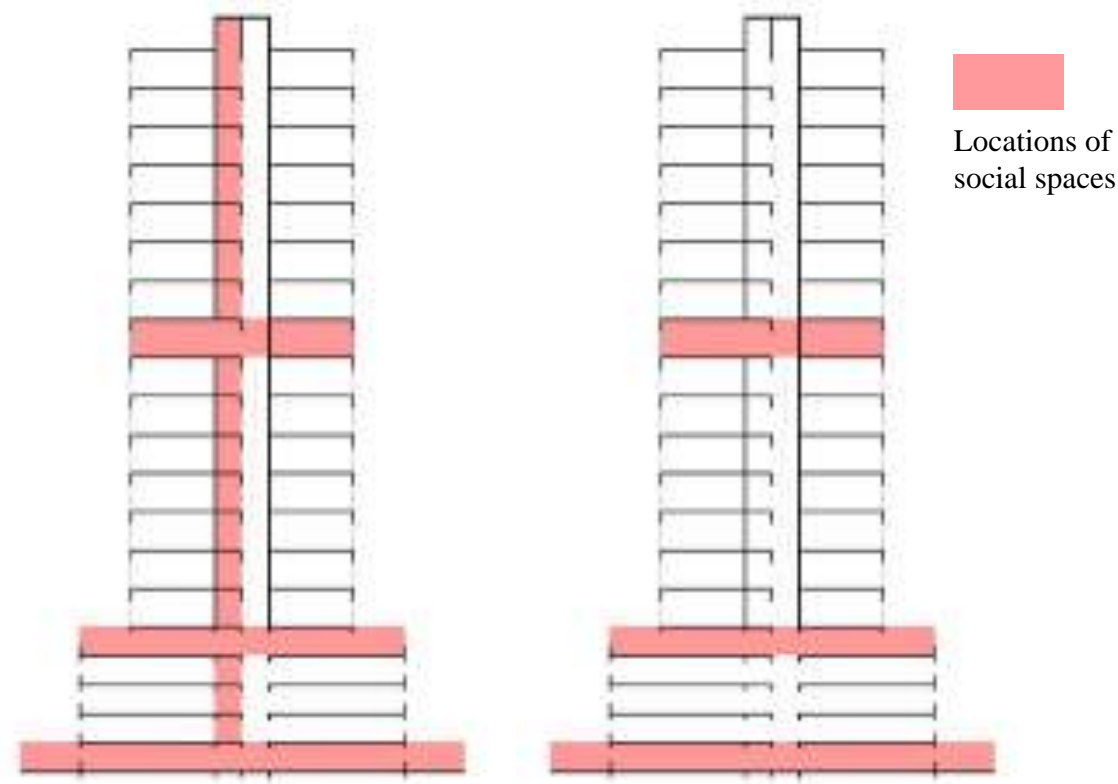

Figure 10: Current locations of social spaces \& Figure 11: Proposed continuity and frequency of social spaces using existing common spaces

The comparison criteria are adapted from Nugent's (2012) research on successful residential common spaces and derived from Maslow's Hierarchy of Needs (Maslow, 1954), which groups human needs into three categories and five levels: basic needs comprising physiological and safety needs; psychological needs comprising sense of belonging and self-esteem needs; and self-fulfillment needs comprising selfactualisation. Maslow (1954) posits that one has to satisfy a lower level need before meeting a higher one; for example, one has to fulfil one's need for shelter before one considers a need to belong. However, this paper will consider instead the ability of a common space to fulfil those needs, as in this case the physical environment will provide the means to do so and its utilisation is up to the residents. The last level of selfactualisation will also be disregarded as it is a culmination of achievements of the lower levels and is subjective for every person.

\section{Basic needs criteria}

i) Visibility and openness

The ability to see and to be seen from one's current location is a measure of safety and security. Residents will be able to see anyone coming and going from a space, and as passers-by they may choose to drop in and be involved with activities in the space if they are interested. The visibility of the space from main circulation routes will also be taken into consideration.

\section{ii) Distance from daily travel path}

The more frequented a space is, the safer the space is perceived to be, as residents assume that the presence of witnesses will deter deviant behaviour and in extreme 
Siew Bee, Aw \& Poh Im, Lim

The Provision of Vertical Social Pockets for Better Social Interaction in High-Rise Living

cases, crime, as popularised by Jane Jacobs (1961) with her "eyes on the street" theory. Spaces along the daily path of travel of residents also tend to be used more often, thus increasing opportunities for socialisation (Blossom \& Thompson, 2015).

\section{iii) Effective reach}

The spaces will be evaluated on their effective reach, whether macro (the entire residential high-rise) or micro (only residents in a localised area, such as a single floor).

\section{iv) Noise tolerance}

While ownership and residency of the housing units fulfils the physiological need for shelter, residents also require rest (Maslow, 1954), and as such, the noise tolerance of the common spaces under consideration will also be evaluated based on distance from residential units and observed noise-dampening ability.

\section{Psychological needs criteria}

\section{i) Possibility for multiple activities to take place}

The ability to conduct a variety of activities in a space, from simple conversations to recreational or interactive activities, can contribute towards increasing belongingness and self-esteem. A space that can cater for several different activities will appeal to a wider range of residents.

ii) Possibility of personalising a space

A sense of belonging can also be fostered when residents are given the freedom to personalise a space. It could be as simple as the ability to rearrange furniture to facilitate conversation or to place a vase of flowers. This gives residents the opportunity to take up responsibility for the space and thus for territoriality to form (Newman, 1972).

\section{iii) Quality of space}

The ability of the space to create a third place atmosphere (Oldenburg, 1989) - a relaxed, welcoming and friendly environment conducive for conversation includes the degree to which it is naturally lighted, pleasingly coloured, and comfortably furnished (Nugent, 2012). Residents will be more likely to use a space if a satisfying quality has been achieved.

Based on these seven criteria, the existing semi-public spaces available in residential high-rises are evaluated for their suitability to be enhanced as a social space conducive for the formation of micro-communities. The findings are summarised in the table below:

Table 1: Evaluation of existing semi-public spaces in residential high-rises.

\begin{tabular}{|l|l|l|l|l|l|l|l|}
\hline $\begin{array}{l}\text { Semi- } \\
\text { public } \\
\text { space }\end{array}$ & $\begin{array}{l}\text { Visibility } \\
\text { \& openness }\end{array}$ & $\begin{array}{l}\text { Distance } \\
\text { from daily } \\
\text { travel path }\end{array}$ & $\begin{array}{l}\text { Effective } \\
\text { reach }\end{array}$ & $\begin{array}{l}\text { Noise } \\
\text { tolerance }\end{array}$ & $\begin{array}{l}\text { Multi- } \\
\text { activit } \\
\text { space }\end{array}$ & $\begin{array}{l}\text { Space } \\
\text { persona- } \\
\text { lisation }\end{array}$ & $\begin{array}{l}\text { Quality of } \\
\text { space }\end{array}$ \\
\hline $\begin{array}{l}\text { Green } \\
\text { area }\end{array}$ & High & Moderate & Macro & High & Yes & Yes & Good \\
\hline $\begin{array}{l}\text { Commo } \\
\mathrm{n} \\
\text { facilities }\end{array}$ & High & Moderate & Macro & High & Yes & Yes & Good \\
\hline
\end{tabular}




\begin{tabular}{|l|l|l|l|l|l|l|l|}
\hline Corridor & High & Negligible & Micro & Low & No & Limited & Moderate \\
\hline Staircase & Moderate & Negligible & Micro & Moderate & No & No & Poor \\
\hline $\begin{array}{l}\text { Lift } \\
\text { lobby }\end{array}$ & High & Negligible & Micro & Moderate & Yes & Yes & Moderate \\
\hline Car park & Moderate & Moderate & Macro & High & No & Limited & Poor \\
\hline
\end{tabular}

Out of these existing semi-public spaces, this study chooses to improve upon the lift lobby as it fulfils the aim of the study by targeting residents at a micro level at their respective floors, in addition to being highly visible and part of a resident's daily travel path. The increased space afforded to it as the connecting point for corridors emphasises its importance as the nodal point of the floor and allows for some degree of simultaneous varied activities, which makes it a natural sociopetal space for residents living on any particular floor.

\section{The Lift Lobby as an Engine of Social Interaction}

Ample research has been conducted on social interaction in multi-family dwellings (Festinger et al (1950); Glaeser et al (2000); Fleming et al (1985)). Outdoor common spaces have received considerable attention (Kuo et al (1998); Farida (2013); Bouma et al (2010)). However, a micro view on the definition of "community" may be more prudent in view of the growing number of residents per apartment building.

Fleming's findings are partially echoed by Williams (2005), who discovered that positioning a common room centrally in the building layout will encourage more residents to use it. However, the provision of yet another designated common space, and on every floor at that, may strongly deter developers whose profits are already dampened by the construction of price-controlled affordable housing units. The next logical step, then, is to locate existing, under-utilised spaces that are 'central' to the building itself, even if they are not physically in the centre of the building layout. This centre can be perceived as the heart of vertical circulation routes present in all high-rise living, namely the staircase but more commonly, the lift. The lift lobby also fulfills Festinger's conditions for social interaction, as it provides space for chance meetings.

Birchall (1988) discovered an inverse relationship between the size of a residential community and their inclination to use common spaces. The smaller the group, the more likely they are to use the common space and take part in communal activities. Birchall's study casts some doubt on the effectiveness of ground- and podium-level facilities so commonly found in residential high-rises. These facilities are large, meant for all, and used by all, so according to his findings, residents may be less inclined to use them for communal activities, although they may still use them for personal recreation.

Based on these key findings, it can be assumed that the converse also holds true: reducing the number of residents that use a common space which is located centrally in the building will encourage them to use the spaces, thereby promoting social interaction and networking. It is much easier to get to know two dozen neighbours living on the same floor than two hundred residents living in the same block. As both reducing the number of residents per residential project and partitioning common facilities into many smaller blocks are unfeasible and unreasonable, this paper suggests working on creating microcommunities comprising residents of their respective floors, with the lift lobby, an existing, must-use space for circulation, as a cost-effective communal space for social interaction. 
Siew Bee, Aw \& Poh Im, Lim

The Provision of Vertical Social Pockets for Better Social Interaction in High-Rise Living

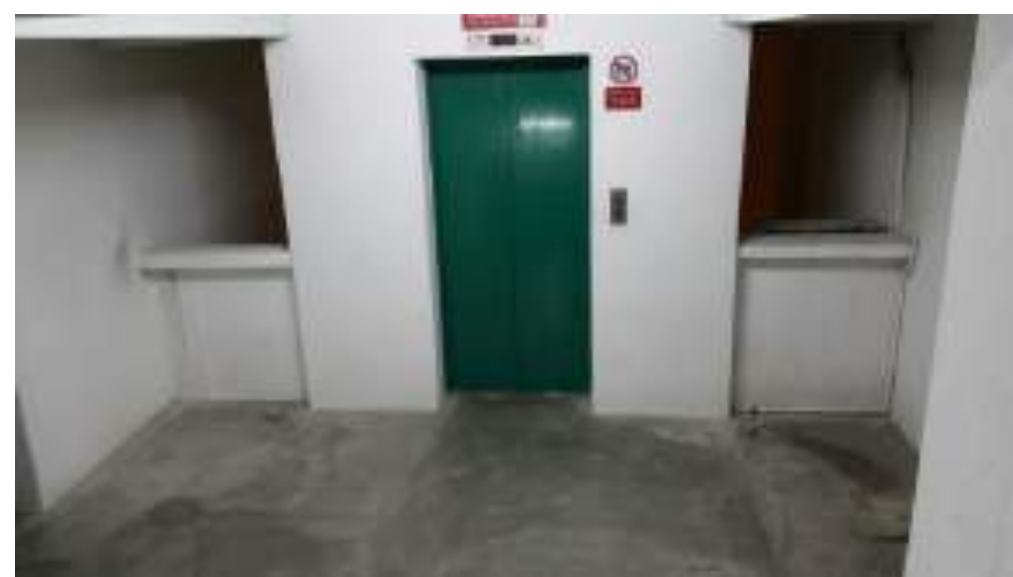

Figure 12: Under-utilised space: an existing lift lobby in an apartment

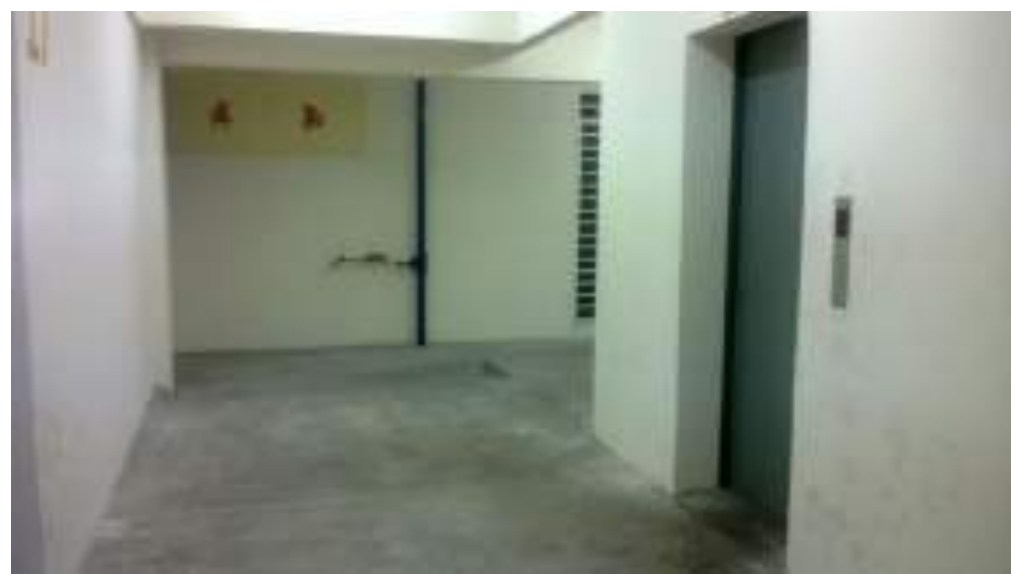

Figure 13: Under-utilised space: an existing lift lobby in an apartment

\section{Suggested Design Interventions}

Furnished lift lobbies are not revolutionary; in fact, they have been used extensively in hotels and corporate offices. Foyers and lift lobbies create the perfect opportunities for place-making indoors. Designers have begun to realise the possibilities of turning such lift lobbies into happening spaces, and it shows in the various wall treatments, light manipulation, furniture and even game areas that have been set up for recreational purposes. A rudimentary effort can sometimes be found in the ground floor lift lobbies of higher-end high-rises in the form of seating and the use of materials. 


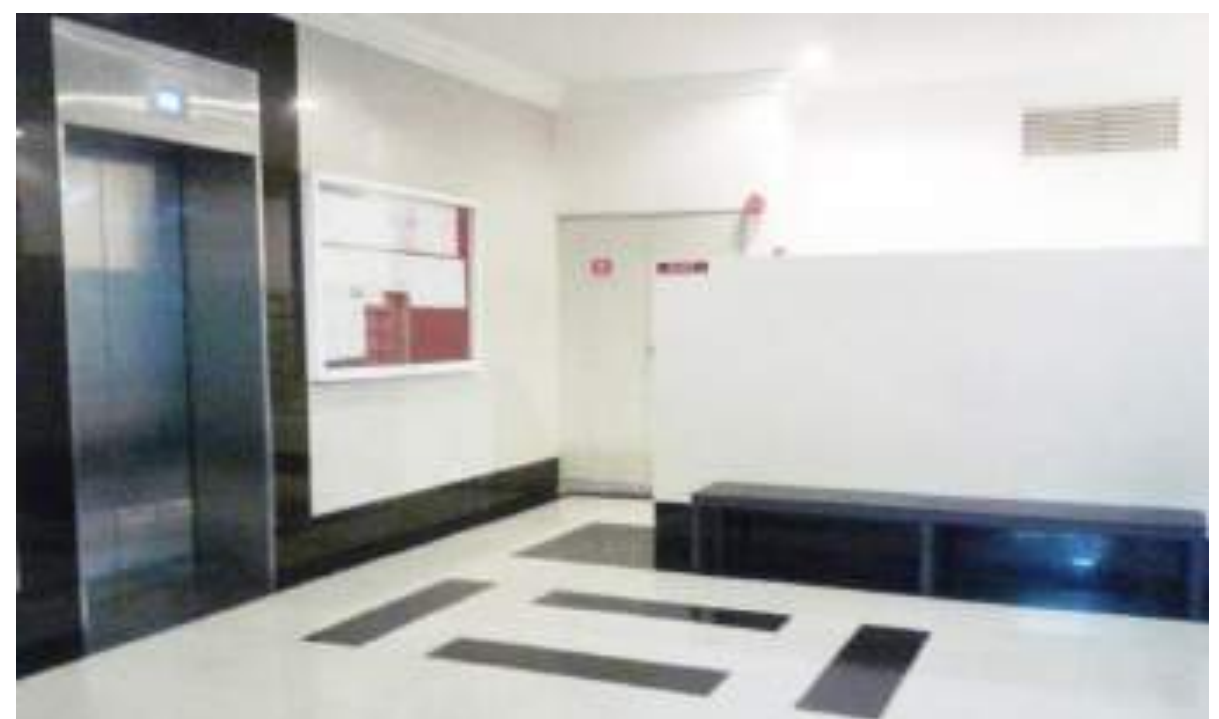

Figure 14: A single bench at the ground floor lift lobby of a condominium in Kuala Lumpur

This particular innovation, however, has yet to be implemented at a micro scale even in luxury homes, much less in lower end or affordable housing schemes. As such, the lift lobbies designated at every floor are under-utilised and redundant for the better part of the day, especially since residents only use it for a few minutes while waiting for the lift to arrive. In sandwich block high-rises, the lift lobby is a prime location for communal activities by simply being wider than the corridor it serves. The extra width allows people to linger if provided the opportunity and incentive to do so, which serves to expose the lingerers to residents coming to and from the lifts, triggering the mere exposure effect.

The first step is to create a place for them to interact, which gives them a reason to linger longer. In a way, the lift lobby can be re-invented as a public living room for residents who wish to chat without bringing regular friends into the inner sanctum of their home. These design interventions need not take up much space. One simple, straightforward way to do that is by installing benches or chairs parallel to or facing the lift lobby so that residents may sit there to rest or chat. Potted plants can be used to enliven the space and mark the pocket 'boundary' for social interaction. Likewise, the colours and materials used for the floor can be used to delineate the social space from the normal flow of circulation. Low walls at the exterior end of the lift lobbies can be reimagined as magazine racks, herb gardens, and so forth to create opportunities for small community projects. If the lobby is wide enough, furniture can be arranged to create several pockets of space for several small groups to converse at the same time. Portable furniture can also be used so that residents may create their own space to suit their needs. Besides being inspired by the living room, the lift lobby can also take cues from cafe design. Chairs, benches, and tables of varying types and heights can be used to accommodate different users. Power outlets can be installed for the convenience of laptop users. A counter-top 
Siew Bee, Aw \& Poh Im, Lim

The Provision of Vertical Social Pockets for Better Social Interaction in High-Rise Living

can even be installed as a make-shift communal pantry and double up as a discussion table when the situation calls for it.

Below are several possible interpretations of the lift lobby as an enabler of social interaction. There are endless configurations to be explored; the images are but a few illustrations of the ability of the lift lobby to become more than just circulation space.

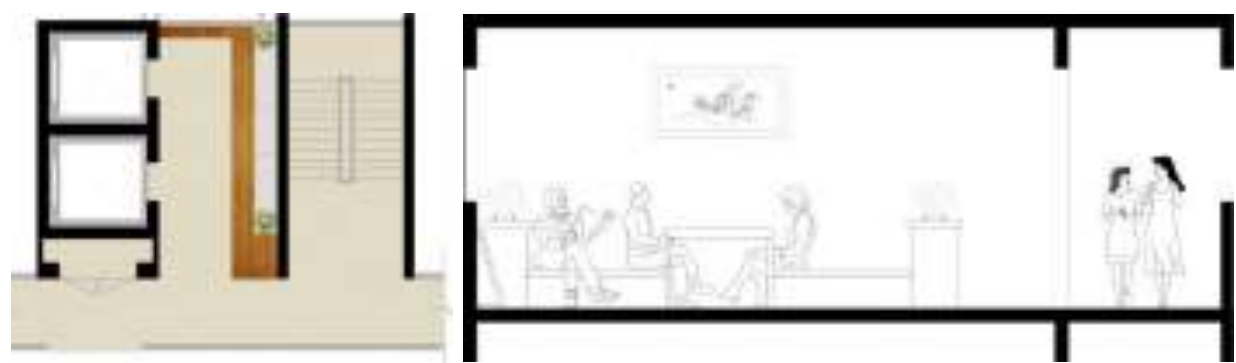

Figure 15 \& 16: Redesigned lift lobby with a narrow width by adding built-in furniture and demarcated zones with differentiated materials, using the lift lobby layout from

Figure 6.

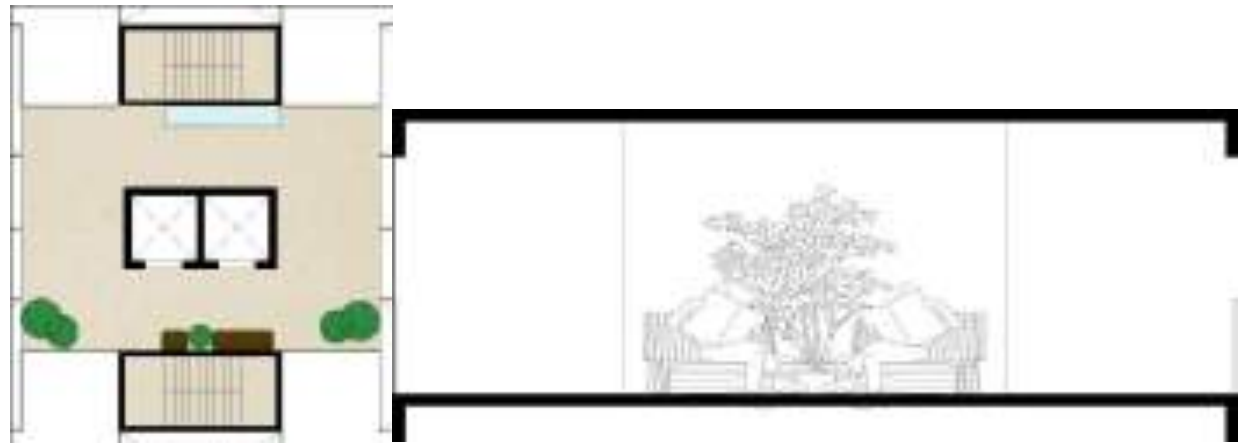

Figure $17 \& 18$ : Redesigned lift lobby with a narrow width by adding built-in furniture and demarcated zones with differentiated materials, using the lift lobby layout from

Figure 7

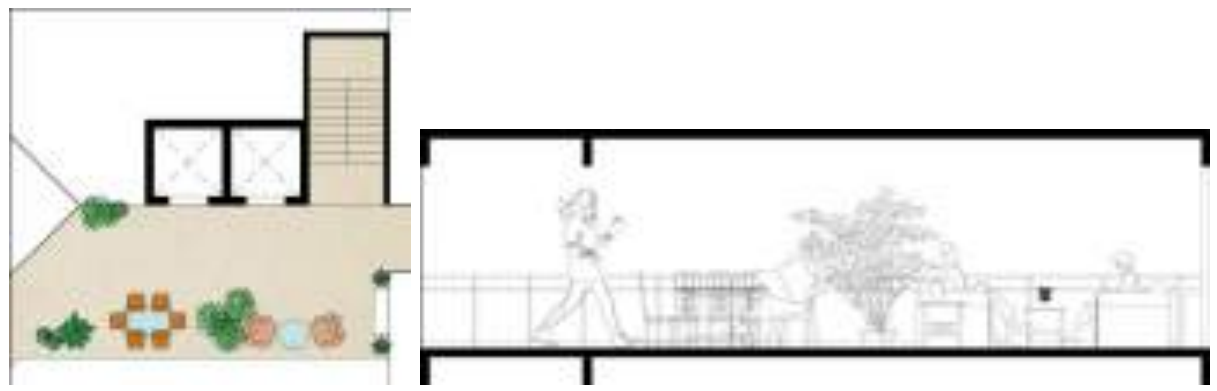

Figure $19 \& 20$ : Redesigned lift lobby with fixed and portable furniture, plants, a counter-top, and power outlets, using the lift lobby layout from Figure 8 


\section{CONCLUSION}

This study addresses the limited effectiveness existing stratified social spaces in creating social relationships among residents of high-rise dwellings. Various studies have shown that 'less is more' when it comes to the capability of a designated social space to promote meaningful, lasting interaction; keeping the spaces small but numerous will allow for the formation of more micro-communities. The spaces need not be dedicated for social interaction; they can occur anywhere there are redundant, visible spaces in the building, such as the lift lobby, which is currently under-utilised as merely a transitional space. The lift lobby is a prime location as it is in the middle of the building in sandwich block layouts, the most common layout found in high-rises priced between RM100,000 and RM400,000. It can be furnished to encourage lingering and increase passive contact among residents. Once micro-communities have had the chance to form, further studies will be required to further unify the residents, from being parts of a micro-community to a part of a whole vertical neighbourhood.

It should also be noted that the proposed design intervention is minimal and can be implemented even in existing buildings. Such simple but purposive intervention can possibly address the single-use redundancy of transitional spaces, improve semi-public spaces, foster social interaction, and create a harmonious rapport among high-rise residents. With the current phenomenon of large building footprints and site coverage prevalent in Malaysia, which constrains the horizontal development of better social spaces, an alternative would be to grow upwards; the creation of sociopetal vertical social pockets via lift lobbies is one that can be easily incorporated. Further studies and innovations need to be brought in, in order to enrich the social fabric of residents.

\section{REFERENCES}

Baum, A. and Valins, S. (1979) Architectural Mediation of Residential Density and Control: Crowing and the Regulation of Social Contact. In L. Berkowitz, (Ed.), Advances in Experimental Social Psychology, pp. 131-175, San Diego, CA: Academic Press.

Birchall, J., (1988) Building Communities the Co-operative Way, London: Routledge \& Kegan Paul.

Blossom, N. and Thompson, J. A. A. (2015).The Handbook of Interior Design.UK: WileyBlackwell.

Bouma, J. T., Poelman, W. A. and Voorbij, A. I. M. (2010) Supporting Social Contact Design Principles in Common Areas of Housing Communities. Researcher (PhD.), Hanze University of Applied Research, Groningen, University Twente.

Conklin, J. E. (1971) Dimensions of Community Response to the Crime Problem, Social Problems, No. 18: 373-385.

Day, C. (2002). Spirit and Place: Healing Our Environment. Oxford: Architectural Press.

Evans, G. W., Rhee, E., Forbes, C., Allen, K. M., Lepore, S. J. (2000) The Meaning and Efficacy of Social Withdrawal as a Strategy for Coping with Chronic Residential Overcrowding, Journal of Environmental Psychology, No. 20: 335-342.

Evans, G. W. (1979). Behavioural and Physiological Consequences of Crowding in Humans, Journal of Applied Social Sociology, Vol. 9, 1:27-46.

Farida, N. (2013) Social Interaction in Communal Outdoor Spaces of Residential Housing Estates in Biskra-Algeria, International Journal of Environment, Ecology, Family and Urban Studies, Vol. 3, No. 1: 45-58. 
Siew Bee, Aw \& Poh Im, Lim

The Provision of Vertical Social Pockets for Better Social Interaction in High-Rise Living

Festinger, L., Back, K. W. and Schacter, S. (1950) Social Pressures in Informal Groups: A Study of Human Factors in Housing, Stanford, CA: Stanford University Press.

Fleming, R., Baum, A. and Singer, J. E. (1985) Social Support and the Physical Environment In: Cohen, S. and Syme S.L. (Eds.), Social Suport and Health, pp. 327-345,Orlando, FL: Academic Press.

Freedman, J. L., Klevansky, S. and Ehrlich, P. R. (1971). The Effect of Crowding on Human Task Performance, Journal of Applied Social Psychology, Vol. 1, No. 1:7-25.

Glaeser, E. L. and Sacerdote, B. (2000) The Social Consequences of Housing, Journal of Housing Economics, No. 9: 1-23.

Hazan, C. and Shaver, P. (1987) Romantic Love Conceptualisation as an Attachment Process, Journal of Personality and Social Psychology, Vol. 52, No. 3: 511-524.

Jacobs, J. (1960) The Death and Life of Great American Cities. New York: Random House.

Kneis, G. (2009) The Effects of Mobility on Neighbourhood Social Ties. SOEPpapers on Multidisciplinary Panel Data Research, No. 175, Berlin: SOEP.

Kuo, F. E., Sullivan, W. C., Coley, R. L. and Brunson, L. (1998) Fertile Ground for Community: Inner-City Neighbourhood Common Spaces, American Journal of Community Psychology, Vol. 26, No. 6: 823-851.

Le Corbusier (1967). The Radiant City. New York: Orion Press.

Malaysia, National Property Information Centre (2014) Residential, Shops and Industrial Properties Market Status Report H1 2014, Kuala Lumpur: NAPIC.

Malaysia, Town and Country Planning Department (2011) Draft Planning Guidelines for Common Facilities, Kuala Lumpur: JPBD.

Maslow, A. H. (1954) Motivation and Personality. New York: Harper \& Row.

McCarthy, D. and Saegert, S. (1979) Residential Density, Social Overload, and Social Withdrawal. In J. R. Aiello \& A. Baum, (Eds.), Residential Crowding and Design, pp. 55-75, New York: Plenum Press.

Community, http://www.merriam-webster.com/dictionary/community (retrieved date: 25 March 2015)

Mitchell, R. E. (1971). Some Social Implications of High Density Housing, American Sociological Review, Vol. 36, No. 1:18-29.

Newman, O. (1972). Defensible Space. New York: MacMillan.

Newman, O. (1976). Design Guidelines for Creating Defensible Space. Washington: National Institute of Law Enforcement and Criminal Justice, Law Enforcement Assistance Administration, U. S. Dept of Justice.

Nugent, J. (2012). Residential Common Spaces that Really Work. Planning for Higher Education, Vol. 41, No. 1: p234

Oldenburg, R. (1989) The Great Good Place. New York: Parragon Books.

Stets, J. E. and Burke, P. J. (2005) A Sociological Approach to Self and Identity. In: Mark Leary and June Tangney (Eds.), Handbook of Self and Identity, pp. 128-152, New York: Guilford Press.

Taylor, J. T., Jackson, J. S., and Chatters, L. M. (Eds.) (1997). Family Life in Black America. Thousand Oaks, CA: Sage Publications.

Williams, J. (2005) Designing Neighbourhoods for Social Interaction: The Case of Cohousing, Journal of Urban Design, Vol. 10, No. 2: 195-227. 